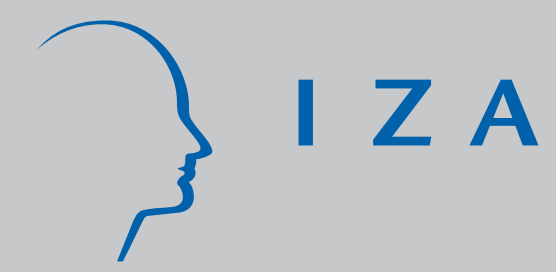

IZA DP No. 6429

An Examination of the Work History of Pittsburgh Steelworkers, Who Were Displaced and Received Publicly-Funded Retraining in the Early 1980s

Robert W. Bednarzik

Joseph Szalanski

March 2012 


\title{
An Examination of the Work History of Pittsburgh Steelworkers, Who Were Displaced and Received Publicly-Funded Retraining in the Early 1980s
}

\author{
Robert W. Bednarzik \\ Georgetown Public Policy Institute \\ and IZA \\ Joseph Szalanski \\ Former CEO of Management Decisions Inc.
}

Discussion Paper No. 6429

March 2012

\author{
IZA \\ P.O. Box 7240 \\ 53072 Bonn \\ Germany \\ Phone: +49-228-3894-0 \\ Fax: +49-228-3894-180 \\ E-mail: iza@iza.org
}

Any opinions expressed here are those of the author(s) and not those of IZA. Research published in this series may include views on policy, but the institute itself takes no institutional policy positions.

The Institute for the Study of Labor (IZA) in Bonn is a local and virtual international research center and a place of communication between science, politics and business. IZA is an independent nonprofit organization supported by Deutsche Post Foundation. The center is associated with the University of Bonn and offers a stimulating research environment through its international network, workshops and conferences, data service, project support, research visits and doctoral program. IZA engages in (i) original and internationally competitive research in all fields of labor economics, (ii) development of policy concepts, and (iii) dissemination of research results and concepts to the interested public.

IZA Discussion Papers often represent preliminary work and are circulated to encourage discussion. Citation of such a paper should account for its provisional character. A revised version may be available directly from the author. 


\title{
ABSTRACT
}

\section{An Examination of the Work History of Pittsburgh Steelworkers, Who Were Displaced and Received Publicly-Funded Retraining in the Early 1980s}

\begin{abstract}
A gap in the displaced worker-training literature is that the post-retraining period has not been studied over the long term. The approach here will be to examine in-depth the experience of a selected few displaced worker trainees over a 20 to 25 year period following their training. With our small sample, but in-depth examination, we will begin to remedy this gap in the literature. To understand better the training programs available for displaced steelworkers, we also interviewed people involved with the development and delivery of training. Further, when we discovered the grass roots growth of organizations to help displaced workers generally, we interviewed them as well. Our findings of the experience of 30 displaced steelworkers in Pittsburgh confirm those in the literature of training program attributes that increase the likelihood of their leading to a job. They include programs that are small scale, linked to the local job market, and focus on developing analytical skills. Two other key components perhaps helping account for the retraining success were assessment and auditing. Entrance into the training program required an intensive screening or assessment process to ensure that (1) the program was right for them, and (2), more importantly, they were capable of handling and grasping the content of the training. Helping displaced workers with tuition payments at a community college also has merit.
\end{abstract}

JEL Classification: J24, J68

Keywords: $\quad$ training, displaced workers

Corresponding author:

Robert W. Bednarzik

Georgetown University

Georgetown Public Policy Institute (GPPI)

3520 Prospect Street, NW

Washington, D.C. 20007

USA

E-mail: bednarzr@georgetown.edu

\footnotetext{
* Paper was funded by Kalmanovitz Initiative for Labor and Working Poor, Georgetown University under the K1 Faculty Summer Research Grant Program.
} 


\section{$\underline{\text { Introduction }}$}

There has been a long-term policy debate of the value of government-sponsored training for displaced workers. They are usually defined as persons who have permanently lost their job because of a plant shutdown or large-scale layoff. The Federal government's first attempt to provide training to displaced workers was the Manpower Development and Training Act (MDTA) in 1962. It was followed by the Comprehensive Employment and Training Act (CETA) in 1973, Job Training and Partnership Act in 1982, and the current Workforce Investment Act (WIA) enacted in 1998. Concurrent with these endeavors was help for workers displaced because of trade under evolving trade adjustment assistance (TAA) schemes. For most of the 1980s, however, the Reagan Administration's philosophy of new Federalism made the states the key intergovernmental player in developing social policy including training policy. By the late 1980s, only six states had not committed funds to subsidize training. Evaluations of the training component in these programs for displaced workers were extensive and costly. Evaluation methods ranged from pre/post outcomes to randomly selected control groups. The typical result was that the training did not work very well in terms of helping training participants find reemployment at a comparable wage. Post-period examination of outcomes was typically only a few months to two years after completion of training. Debate railed that this simply was too soon to see conclusive results. The approach here will be to examine in-depth the experience of a selected few displaced worker trainees over a 20 to 25 year period following their training. This will help fill a large gap in the literature and our knowledge of the value of training. The trainees were displaced steel mill workers in the Pittsburgh, Pennsylvania area who lost their jobs and received publically funded training in the 1980s. 


\section{Pittsburgh steel mills in the 1980s}

The American steel industry entered into a major economic crisis in the early 1980s, systematically closing its largest production facilities. Almost overnight thousands of jobs were eliminated. For example in 1986, U.S. Steel locked out thousands of its employees when it shut down a number of plants as a result of a drop in orders on the eve of a threatened strike. In addition, U.S. Steel and other steel producers demanded extensive concessions from their employees in the early 1980s. In a letter to striking employees in 1986, J. Bruce Johnston, U.S. Steel executive vice president warned, "There are not enough seats in the steel lifeboat for everybody." (New York Times, 1986) Indeed, an estimated 30,000 steel worker jobs were lost in the 1980s in Pittsburgh. Why? A debate raged among the people we talked to with many blaming the company's unwillingness to innovate and others blaming the union for unrealistic wage and benefit demands. For our project, we can say the reason does not matter because people still had to figure out a way to survive as the steel mills were not reopening. For the record it appears both arguments on why the mills closed had merit.

The 1970's world steel industry was characterized as overbuilt; that is, there was excess capacity. (Crandall, 1980) In the late 1970s, moreover, the U.S. dominance in steel production started to fade. After commanding 47 percent of the world's raw steel production in the 1950s, the 1970s saw American steel producers facing increasing competition from abroad. Foreign steel mills were in large part newer, equipped with more modern, cost-efficient technology, and operating with relative lower labor cost. These lower production costs enabled foreign producers to capture a steadily increasing share of the American steel market, doing so in a period of overall market contraction. (Leff, 1986) By successfully citing unfair trade practices under the 1974 free trade act and limiting steel imports, the U.S. steel industry was able to delay its 
downfall. Still, changing global economic competitiveness led eventually to U.S. steel industry profits plummeting relative to other manufacturing sectors, and a corresponding decline in capital investments.

U.S. steel producers did engage in an extensive effort to reduce excess capacity by creating smaller, more efficient and competitive divisions. Many large-scale producers shut down and others were drastically reduced in size. There were also some late attempts to save the mills, with the United States Steelworkers of America agreeing to an industry wide 9 percent wage and benefit reduction in 1983. A feasibility study by Locker/Albrecht Associates showed that some departments could be made competitive and profitable, but nothing could reverse the corporate decision to virtually abandon the steel industry in the Pittsburgh area. The huge mills that had been a part of the Pittsburgh landscape and culture for over a century would disappear, along with the financial security for more than 30,000 people cast into joblessness.

As steel mills closed, it is important to be reminded of the expectations in the workplace and state of the economy of that era. It was a time, much different from now, when people believed they would spend their entire working lives with one employer, a feeling particularly true in the steel industry. Steel workers were often the second or third generation into the mill, with the thought their children could follow them in if they so chose. These expectations of stability and security were shattered, jobs were lost, some mills completely razed, and people who thought they would never have to look for a job again were suddenly forced to do so.

They were thrown into a job market that was severely ravaged and devastated, with the regional economy sinking to levels not seen since the Great Depression. In the decade of the 1980s, 100,000 manufacturing jobs were lost in the Pittsburgh area, with corresponding cuts in 
the service and retail sectors substantially increasing the number of people thrown into joblessness.

Such dismal conditions attracted national attention, with a few of our survey respondents reporting being interviewed multiple times in those years by the media, union officials, academics, and community agencies. Our interviews were structured to encourage the participants to express their attitudes and feelings, from both then and now, in addition to examining work histories and the role retraining had on them. Approximately 3,400 dislocated workers were trained under publically funded programs from the mid-1980's to early 1990's in the Pittsburgh area. They ranged in age from 25 to 55 years and about one-third, or 1,100, were displaced steel mill workers, who were mostly men and slightly disproportionately black.

In focusing on the retraining, we supplemented our interviews of displaced workers and broadened our scope by meeting with people who designed and delivered the training, along with some influential people involved with a grass-roots movement, all of whom gave an informed perspective of the times. We begin with a discussion of the training infrastructure at that time in Pittsburgh.

\section{$\underline{\text { Training Delivery System }}$}

The massive lay-offs created a gross imbalance in the labor market, too many people after too few jobs, and a challenge to the region's ability to provide retraining on such a scale. But unlike in Chicago when U.S. Steel's South Works was closed in the early 80s, officials of the city of Pittsburgh and Allegheny County felt that they were virtually ready to handle largescale layoffs. After the Chicago shutdown, Locker/Albrecht Associates released a December 
1985 report that concluded "Employment and retraining programs for unemployed steelworkers have been inadequate. In most cases, local and state governments were not prepared to assist thousands of unemployed workers who were suddenly laid-off." Pittsburgh got the message.

In the Pittsburgh region, the Allegheny County Department of Federal Programs was operating a Training and Employment Center in the heart of the hard-hit Mon Valley, in Braddock, running programs primarily for economically disadvantaged and welfare recipients. They sub-contracted with Management Decisions Inc. (MDI) to provide job search and life-skills training for displaced workers, which was initially done at the Braddock Center.

The staff quickly developed programs specifically for displaced workers. They provided assessment as a prelude to referral to an appropriate vocational educational school that had been approved for TAA and other public funding, along with a job search/job club component. Very soon thereafter, the Allegheny County Commissioners directed the local Community College to provide tuition-free access to all displaced workers to any of its vocational, business, or academic classes.

As the mills continued to lay off workers, the Allegheny County Department of Federal Programs received an U.S. Department of Labor grant to establish a retraining complex in downtown Pittsburgh. The new facility was originally only to serve displaced steelworkers, but the scope was expanded to include workers displaced from any type of business.

Diagram 1 illustrates the new operation in Pittsburgh, which became known as the One-

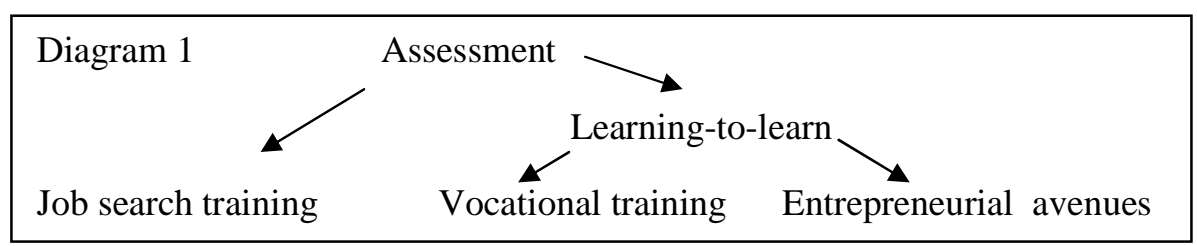

Stop Shop and delivered a more comprehensive 
program than the existing Braddock program. It entailed an initial consultation and evaluation to aid in the assignment to one of three training modules. The assignment, based on mutual agreement between the trainee and staff, was primarily determined by the displaced worker's interests, goals, and skills and abilities. The first of the month-long options was a Job Search, Job Placement module, taught by former Personnel Directors with experience in the hiring process, for those with the desire and capability of immediately re-entering the labor force. The program was complemented by Job Developers who had contacts and credibility in the private sector. For this service to work well, it must provide up-to-date information on both the pool of job seekers and the positions available.

A second option was for displaced workers who needed to upgrade their job skills. This was part of a learning-to-learn module taught by former educators and designed to prepare workers for re-entry to an educational setting and successfully complete a vocational program once enrolled. The Department of Federal Programs contracted with a number of proprietary and vocational schools, paying the tuition and fees for each displaced worker referred to the school. There were also government-funded programs designed in conjunction with local companies for specific jobs, such as those in robotics and fiber optics.

The third module was for those who were undecided about their next step; it consisted of an overview of the hiring process, an examination of training possibilities, and featured an exploration of entrepreneurial avenues in a segment taught by people with small business experience.

We interviewed ex-workers who came out of all the before-mentioned programs, receiving a variety of responses, from how it greatly improved lives to it being totally ignored 
and never used. Regardless of the type of program, to succeed it was clear to us that the aid provided must be well targeted, offer services tailored to local circumstances, and make them easily accessible to those in need.

\section{Counselors and Instructors}

We interviewed vocational counselors and program instructors; people who had sustained and unfiltered contact with displaced workers right at the time of dismissal. Our interest was in discovering any lasting memories and overall expressions that had sufficient impact to be recallable some thirty years later.

Lena Franklin (2011) was a vocational counselor at the Braddock Training and Employment Center, where the first wave of displaced steelworkers went in 1981. Though each worker would have a unique, individual reaction, she remembered a cluster of emotions. There was anger, a sense of betrayal, there was fear of the future, and there was skepticism. Numbers of laid-off workers, especially from the early layoffs, were not convinced the mills would shut down, believing the threat of such to be a management bargaining ploy. Still, there was uncertainty, the fear of facing the future without a full-time job for the first time in their lives. Of those who were earnestly interested in looking for a job, many thought any new job would be temporary until the mills re-opened, and were interested in jobs where pay would be comparable to what they earned in the mill.

It was interesting to get the perspectives of people who had almost immediate contact with displaced workers. We solicited the views of several instructors who taught job search/job club and pre-vocational training throughout the 1980s, in settings designed to illicit active 
participation, allowing instructors to become aware of workers' sentiments and opinions in addition to their skills, abilities, and interests.

The recollections of the earlier classes were similar to those voiced by the counselors, of skepticism, or maybe it was just hope, that the mills really would not be shut down. There was also the anger and sense of betrayal when it became more apparent that they would. These were people who opted for security and stability, people who had expected to follow the paths of previous generations, of spending an entire work life in the steel mill. Now these expectations were shattered, they felt their lives shattered, and emotions ran deep in the classroom.

To most steelworkers of that era, a job search consisted of going to the mill's employment office, filling out an application, and being assigned a job. They never envisioned having to seek out employment opportunities and competitively interview for them. When they came into the classroom, it was the beginning of a whole new world.

As the anger subsided, as time passed and new groups came through that were further removed from the initial shock, the displaced workers became a good group to work with. This was life at its most basic, people fighting for survival, trying to re-establish a future that recently appeared to have been stolen from them.

With their emotions more under control, it became apparent that many were intelligent, informed people, disputing the stereotype of the strong-backed, blue-collar mill hunky. Using the impetus of the 1974 Steel Industry Consent Decree ${ }^{1}$, there were more women in the mills than one might expect. Several of the women we interviewed had a Bachelor degree, choosing

\footnotetext{
${ }^{1}$ Reformed plant seniority systems to accommodate equal employment opportunity. (Ichniowski,1981)
} 
the mill for its' higher wages and benefits and thought-to-be job security. Others lacked the financial wherewithal to pursue advanced education, or opted for the security once promised by the mills, and yet others simply preferred physical work. The stereotype obscures the level of responsibility borne by steelworkers. They worked with large, expensive machinery, charged with operating it with precision and safety, where mistakes could damage corporate profits and fellow workers. Several respondents sadly recalled witnessing serious accidents and fatalities in the mill.

Working in these conditions bred capable, exemplary employees, too many of whom had to leave Western Pennsylvania because of the imbalance in the job market. Re-location was a much-discussed topic in the classes. Family roots run deep in the Pittsburgh area, several generations of whom often earned their living in the same plant, engendering a strong reluctance against moving. The worker, and often more so the spouse, did not want to pull their children from schools or to leave the people they had long history with, but economic realities of meager job prospects could not be ignored. A 1986 University of Pittsburgh State of the Region Report told that 62,000 , predominately younger, displaced workers left the Pittsburgh area to seek work elsewhere. An updated 1990 report chronicled a net migration of 112,000 people from Allegheny County from 1980 to 1988 . The steelworkers we talked to sadly recalled the advice given to young people at that time was "get educated and get out." 


\section{$\underline{\text { Administrators }}$}

We stepped away from those who had hands-on, day-to-day contact with displaced workers and talked with people who were instrumental in setting up and operating the training delivery system. Ronald Quinn (2011) was the manager for the Allegheny County Department of Federal Programs, and helped plan the training options for the initial group of displaced workers that went to the Braddock Training and Employment Center. When it became clear that the magnitude of the shutdowns would grow, that thousands more steelworkers would be thrown out of work, the Department with federal money established the afore-mentioned training facility in downtown Pittsburgh to serve only steelworkers. The project, though well conceived and supported by the United Steelworkers of America, attracted virtually no trainees. Reasons for this lack of displaced steelworker support were never officially discerned, but suspicions lie with the difficulty and costs involved with commuting to the city and ill-will that festered between laid-off workers and some local union officials. Also, it was not uncommon for us to hear that there was an expectation that the mills would reopen, a notion kept alive by the "indefinite layoff" status the companies placed on workers in order to postpone costly retirement and severance payments, so why bother with retraining.

A similar lack of worker enthusiasm for training was reported in a University of Pittsburgh survey in one particular steel town in Mon Valley, with the report stating "the small number seeking retraining raises a question of why." (University of Pittsburgh, 1986) The study concluded that the main reasons were the tradition of self reliance among this population as well as they felt the training would not be helpful. In other industries where the laid-off workers did not harbor hopes of recall, retraining was more readily accepted (University of Pittsburgh, 1984). 
After the Allegheny County Department of Federal Program's initial attempt in downtown Pittsburgh failed, it adjusted its scope of services and created what became known as the One-Stop Shop. This program was exclusively for displaced workers, but open to workers displaced from any type of business, no longer limited to ex-steelworkers. Laid-off steelworkers had frequented the One Stop Shop, in small numbers at first, then more as word of mouth spread and acceptance grew. Some of our respondents participated in this program, which received regional and national attention, attracting visits from members of Congress and the Pennsylvania Secretary of Labor.

\section{Grassroots Movement}

While interviewing displaced workers, we heard numerous references to grass-roots organizations that sprouted in the Mon Valley in response to the massive lay-offs. These groups were formed by ex-workers in efforts to help themselves and each other; giving needed support and direction. Such a response is not surprising in a culture having little history of dependence, and one with a proud tradition of self-reliance. Left with a hatred of the company, a disappointment with the union, and lack of confidence in government, they were reluctant to seek help from anyone outside of their families, their churches, and from each other. Several respondents said that they tried to avoid going on "welfare" because it carried a negative stigma.

Workers organized a community of resistance, formally identified as a movement of the unemployed. (Anderson, 1996) For example, newly established in 1982, the Mon Valley Unemployed Committee (MVUC) organized rallies, often directed at the federal and state governments, to demand positive changes and enactment of new laws for the unemployed. 
MVUC was born out of the collapse of the steel industry in Southwest Pennsylvania. Dislocated workers, clergy and community leaders stepped forward to respond to the catastrophic events. It is a grassroots organization that helps unemployed and dislocated workers gain access to unemployment compensation, retraining, relocation and other benefits they need to remake their lives. It does not charge for its services and instead, receives the majority of its funding through donations from its clients and the unions that have good relations with MVUC. It still serves the Mon Valley region, which is still struggling to recover from the once thriving steel industry with an annual budget of $\$ 130,000$ mostly from United Way. In addition to organizing the community in public gatherings to raise awareness about unemployment, they help unemployed and dislocated workers by offering two main programs: Homeowners' Emergency Mortgage Assistance Program (HEMAP) and Unemployment Compensation (UC) Claim Assistance

Other prominent and effective organizations established at that time were the Steel Valley Unemployment Committee, and the Tri State Conference on Steel. They were led by displaced workers who were most familiar with what type of assistance was available and where and how to get it, and by ex-workers experienced enough in grievance procedures to ensure that fellow dismissed workers received back pay, severance benefits, and early retirement pensions that the company had been reluctant to pay.

The unemployment committees organized food banks that became national models. For example, the Mon Valley Unemployment Committee encouraged people in the valley who were still working to earmark their United Way contributions to the Committee; the funds were used to help support the food banks and provide other financial assistance. The movement attracted national media attention when it worked with county government officials to persuade banks not to foreclose on thousands of houses in the area that were subject to such actions. Several leaders 
in the grassroots efforts became deeply committed to helping other ex-steelworkers find jobs, keeping contacts with those who found work in other states and encouraged them to reach back and assist others who were willing to re-locate.

We talked with several people who assumed leadership roles with the grassroots movement, all of them are still active in support of labor causes. Three were displaced workers, two from steel mills, and a fourth is a Catholic priest. Interestingly, all three of the displaced workers moved into the area from out of state, drawn by the security of large manufacturing. One worked on the shop floor while holding a $\mathrm{PhD}$, later becoming a professor of labor history and authoring several books on the subject, another is presently the Executive Director of a nonprofit agency devoted to economic and social causes, while the third runs a small business that hires only ex-steelworkers and people with disabilities. The priest maintains a state-wide affiliation with the AFL-CIO and supports local USW causes. From them, we heard some compelling human stories of the times from people who were deeply involved. We heard of displaced workers who got their lives back together, we heard of others who tragically took theirs. (McCosllester, O’Malley, Oursler, and Stout, 2011). A local 1985 Mon Valley study confirmed that unemployment and suicides can be related, finding that the 1984 suicide rate in the Mon Valley was double the national rate. (Corbett, J, 1985)

\section{Displaced Workers}

Through the training records of MDI and other sources, we identified 30 dislocated steel workers for in-depth interviews. Our main interest was in their work histories subsequent to training. (See Survey Questionnaire in Appendix for detailed questions). On one hand, it seems 
like participating in training in a deep economic downturn like the one that hit Pittsburgh in the early 1980s is not very smart; there are few jobs available. On the other hand, opportunity cost is lower if unemployed; why not use idle time to invest in your future. In a recent paper using a 10-year time period with administrative data for Germany, Lechner and Wunsch (2009) found a positive relationship between the effectiveness of training and unemployment. So, perhaps taking up a training program when times are bad is not such a bad idea.

We included a range of ages from 50 to 80 years for interviewees in order to have a comprehensive view of experiences, including those still working, those contemplating retirement, and those already retired. We also included a few displaced workers who did not participate in training for comparative purposes. However, before going into the details of our findings, a succinct review of the displaced worker-training literature will be presented. This will allow us to quickly see how our findings contribute to it.

Since a few studies have already tackled reviewing the relevant literature (Leigh, 1990 and 1995; Nigel, 2009; and O'Leary, 2010), it is only necessary to summarize their findings and fill in a few gaps. Examining primarily U.S. displaced worker training demonstration projects which used rigorous methods such as random assignment to a program or a control group to evaluate programs, Leigh (1990) found no clear evidence that classroom training was effective on improving employment and earnings of displaced workers. However, he saw some successes when the curricula were tailored to trainees' backgrounds and the needs of local employers; job search training was deemed cost-effective. (Leigh 1990 and 1995). Nigel (2009) culled the extensive international literature on outcomes of training programs generally and mainly in OECD countries and found training programs that worked best were small scale, targeted on particular worker groups or on particular skills and occupations and linked to practical job 
experience. O'Leary (2010) revisited and updated Leigh's 1990 report and pointed out that the only two experimental evaluations of displaced worker programs were flawed. He concluded that we have not fully tested the impact of skills training for dislocated workers. However, he noted that less rigorous evaluations of U.S. job training for displaced workers found it to be effective, increasing employment rates and generating higher earnings (especially for women). Success was also seen in a program for displaced steelworkers, aged 16 to 53 years in Austria. Evaluation with a treatment/control methodology found the program raised wages and improved employment prospects over a 5-year post-program experience. (Rudolf, 2006) Success was due to joint financing by worker, government and company, plus a combination of services including job counseling, search activities and training (and could receive unemployment benefits while in training for up to 4 years). (Rudolf, 2006) Also successful was community college training in the United States. Jacobson, Louis S. and Robert J. LaLonde (2005) found that 1 year of community college schooling in the State of Washington raised male displaced workers wages by 7 percent (and more for women) and more if they completed quantitative courses. Interestingly, much of the community college cost was funded by the displaced workers themselves.

In summary, the literature appears to show that occupational training for displaced workers has a higher probability of success if the following components are in place:

- Small scale

- Linked to the local job market

- Focus on developing analytical skills

- Worker partly funds the cost 


\section{Pittsburgh Sample Profile}

A profile of our sample can be seen in tables 1

and 2. Average age was 67 years, and the distribution was somewhat evenly spread among the 50-80 year age

Table 1. Age of respondents

\begin{tabular}{|l|c|l|}
\hline Age & Number & percent \\
\hline $50-59$ years & 9 & $30 \%$ \\
\hline 60-69 years & 14 & $47 \%$ \\
\hline 70 and over & 7 & $23 \%$ \\
\hline Average age & \multicolumn{2}{|c|}{67 years } \\
\hline
\end{tabular}

Table 2. Demographics of respondents

\begin{tabular}{||l|c|c|}
\hline category & Number & Percent \\
\hline White & 23 & $77 \%$ \\
\hline Black & 7 & $23 \%$ \\
\hline & & \\
\hline Male & 23 & $77 \%$ \\
\hline Female & 7 & $23 \%$ \\
\hline & & \\
\hline Married & 21 & $70 \%$ \\
\hline Not married & 9 & $30 \%$ \\
\hline & & \\
\hline Veteran & 10 & $33 \%$ \\
\hline Not veteran & 20 & $67 \%$ \\
\hline
\end{tabular}

range of all respondents. Table 2 shows our sample is disproportionately male relative to the overall U.S. workforce, at about three-fourths of the respondents, but this mirrors the make-up of the steel industry. Similarly, one-fourth of our respondents are black, higher than the general workforce but more in line with the steel industry in Pittsburgh. A disproportion of our respondents were married and veterans, the former

likely due to the number of young steel workers who left town following the shutdown of many steel mills. Older workers (and likely married) were more likely to remain. Charles McCollester, an Indiana University of Pennsylvania labor historian commented that the heavy out-migration of young workers in the 1980s left Pittsburgh with an hour-glass demographic profile - the 20 and 30 year olds had left town. (McCollester, 2011) Although several of our respondents confirmed this outward mobility, they said that black steelworkers who lost their jobs were not very likely to relocate.

An overview of our work histories findings says that we have 30 individual and unique stories. For example, there were successful and unsuccessful career changes, business startups, and retirements. Among the four respondents not interested in training, one retired immediately and one returned to work more hours at his barbershop. One successfully wrote a grant and 
received money to launch a business helping displaced workers having difficulties paying their utility bills, while another started his own print shop. Among the trainees, some remained in manufacturing while others chose new careers in nursing, photography, writing, and community development. Several self reported that they had a bachelor's degree, as we did not ask an education question. A few of them returned to school for a Masters or Ph.D. degree. Some enjoyed successful new careers, while others just moved from job-to-job. Interestingly, very few workers ever really returned to their previous earnings' level, especially when you factor in fringe benefits.

\section{Training Outcomes}

How have displaced workers fared many years, whole careers for some, after their training was concluded? Kodrzycki (1997) in "Training Programs for Displaced Workers: What Do They Accomplish?" said there is a need to study long post-training period, as it has not been studied. With our small sample, but in-depth examination, we will begin to remedy this gap in the literature.

One of the primary reasons many unemployed workers spur retraining is lost earnings. You cannot typically earn any or much money while in training. Economists call this opportunity cost. That is, an indirect cost of training is the wages you are not earning while in training, and this cost is typically higher for longer tenure workers. Indeed, earning losses from job loss were higher and more persistent for those with longer job tenure. Just about all of our respondents accepted lower paying jobs in their first post-displacement job. Jacobson, Louis S., Robert J. LaLonde and Daniel G. Sullivan (1993), using earnings records of Pennsylvania workers displaced between 1980 and 1986, many of whom were affected by the restructuring of 
the American steel industry, estimated that permanent job loss resulting from mass layoff or plant closing reduced future earnings of high-tenured workers by approximately 25 percent 5 years after displacement with little difference by age and gender.

Besides lower post-displacement wages, another characteristic of displacement is a long

\begin{tabular}{|l|c|cc|}
\hline \multicolumn{2}{|l|}{ Table 3. Tenure by occupational training } \\
\hline Tenure & Number & $\begin{array}{l}\text { Participated in occupational training } \\
\text { (long term or 6-months or longer) } \\
\text { Number }\end{array}$ & Percent of total \\
\hline 0-5 years & 8 & 5 & $63 \%$ \\
\hline 6-14 years & 12 & 9 & $75 \%$ \\
\hline 15 years and over & 10 & 4 & $44 \%$ \\
\hline $\begin{array}{c}\text { Total (range was 3- } \\
\text { months to 34 years) }\end{array}$ & 30 & 18 & $60 \%$ \\
\hline
\end{tabular}

spell of unemployment following it. Average duration of joblessness for our respondents was about a year

and a half. However, the range was wide from only a few months to nearly five years. The length was influence by several factors - lack of jobs locally, availability of UI and supplemental benefits for at least two years for many, and participation in long-term training. You would expect those with shorter tenure to the most interested in training from a financial standpoint: (1) their opportunity cost is lower, and (2) they have longer work lives remaining to recoup any training cost. However, as you can see in table 3 , job tenure did not seem to matter in the decision to take up long-term training. It was helpful financially that they were receiving UI benefits and tuition cost was paid for by the program. Somewhat surprisingly, several of our respondents opting for training said steel mill jobs were not coming back and I need to get on with my life. It appears that with the passage of time the realization of the mills not reopening began to set in. Sixty percent of our sample enrolled in long-term, occupational training and embarked on a new career path. What happened to them? 
A few answers to this question can be found by examining the experience of all of our respondents with regard to training, as some decided only to participate in "job search" training. Table 4 illustrates experiences. Three of 10 of our respondents participated in job search training

\begin{tabular}{|c|c|c|c|c|c|}
\hline but none of & \multicolumn{5}{|c|}{ Table 4. Training experience and outcomes } \\
\hline \multirow{2}{*}{ them felt it } & \multirow[t]{2}{*}{ Type } & \multirow[t]{2}{*}{ Number } & \multirow[t]{2}{*}{ percent } & \multicolumn{2}{|c|}{ Helped in finding a job } \\
\hline & & & & Yes & no \\
\hline was helpful & $\begin{array}{l}\text { Total with some type of } \\
\text { training }\end{array}$ & 26 & $87 \%$ & 10 & 16 \\
\hline \multirow{2}{*}{ in finding a } & & & & & \\
\hline & Job search only & 8 & $30 \%$ & 1 & 7 \\
\hline \multirow{2}{*}{ job. } & & & & & \\
\hline & Occupational* & 18 & $60 \%$ & 9 & 9 \\
\hline Digging into & $\begin{array}{l}\text { Long term (6 months } \\
\text { or longer) }\end{array}$ & 17 & $57 \%$ & 9 & 8 \\
\hline their & $\begin{array}{l}\text { Short term (less than } 6 \\
\text { months) }\end{array}$ & 1 & $3 \%$ & 0 & 1 \\
\hline responses a & \multicolumn{5}{|c|}{ *A few respondents (4) had both job search and occupational training } \\
\hline
\end{tabular}

little deeper, however, reveals that a few found jobs through contacts (relatives or friends). And, indeed, this is one of the things they teach in job search training.

In contrast, half of the participants in long-term, occupational training found it helpful in finding a post-displacement job. Interestingly, this contrasts with the results of the retraining program for displaced steel workers in Chicago. (Locker/Albrecht Associates report, 1985) They concluded after surveying 326 steelworkers that there were no measurable gains from participating in skills and vocational training. One of the most successful vocational programs in Pittsburgh's case was in Robotics training developed by the Allegheny County Community College in partnership with Westinghouse. The Community College received the funding and hired Westinghouse personnel to help design the curriculum and teach the course, using expensive Westinghouse equipment in the training. This was an intense 1,064 hour program for the students who were rigorously screened through testing and interviewing, with a pool of 400 
applicants, enticed by the prospect of high-paying jobs, reduced to 20 per class. Our respondents who went through this program were the most laudatory in the assessment of the value of retraining. Norm Koehler (2011), the Community College Administrator responsible for its development, saw the irony of training displaced workers to build robots. Other successful programs were related to electronics and engineering. Jobs in the community in these fields had been identified prior to launching the training.

Our interviews went beyond acquiring data defining the respondents as just displaced workers, subjects of studies to be placed into the appropriate column. We saw them as individuals, some in poor health, and some who lost spouses, others who lost children. With the benefit of history, with the passage of time, after negotiating more of the capriciousness of life, they are better able to put the shocks of the 1980s behind, view the era with less emotion and put it into a broader perspective.

Now, though the hurt of their sudden ouster from security into uncertainty still lingers, they spoke of other aspects of their time in the mills. They talked warmly of the camaraderie, about the pride they had in doing superior work in difficult and dangerous conditions. With sadness, they recalled the accidents, the loss of limb and life that they witnessed. It was also with some sadness that they voiced their views of the present economic situation, in many ways echoing the sentiment of our grass roots' interviews, lamenting the absence of passion and outrage in plant closings and layoffs now occurring, sensing more of an apathy and acceptance, believing such actions are inevitable in our economy.

The displaced workers expressed some bitterness over what happened, but all got on with their lives. They coped as best they could, with several becoming active in the grass-roots 
movement. They never considered themselves Masters of the Universe, and have difficulty understanding those who do and the conditions they have wrought. The steelworkers understood that they produced, the Masters manipulated, the steelworkers helped build a nation with steel that was as strong as claimed, the Masters almost destroyed our financial system with junk they claimed to be AAA rated. The steelworkers were thrown out of their jobs; the Masters get bonuses that exceed steelworkers lifetime earnings. They may have been wondering if this was all a tale told by an idiot.

\section{Policy Suggestions}

It is interesting to note that the mass dislocation of steelworkers in Pittsburgh and other large dislocations around the country were the catalyst for two major U.S. Department of Labor programs launched in 1988 that still exist - the Economic Development and Worker Adjustment Assistance Act (EDWAA) and the Worker Adjustment and Notification Retraining Act (WARN). EDWAA provides funds to States and local sub-state grantees so they can help dislocated workers find and qualify for new jobs. Workers who have lost their jobs and are unlikely to return to their previous industries or occupations are eligible for the program. WARN offers protection to workers, their families and communities by requiring employers with 100 or more employees to provide notice 60 days in advance of covered plant closings and covered mass layoffs.

Our findings confirm those in the literature of program attributes that increase the likelihood of their leading to a job, namely small scale, linked to the local job market and a focus on developing analytical skills. All of the successful retraining programs were carefully targeted 
to local jobs, small in take up and focused on needing analytical skills to succeed. Two other key components perhaps helping account for the retraining success was assessment and auditing. Entrance into any training program required an intensive screening or assessment process to ensure that (1) the program was right for you, and (2), more importantly, you were capable of handling and grasping the content of the training. Concurrently with the training, there was a continual auditing process to ensure the quality of the training infrastructure and instructors, as well as adequate funding was in place to make sure you could complete the program. Job placement rates were also monitored, with the program's refunding success dependent in large part upon the success of its graduates finding jobs.

Some of the successful programs provided free tuition at Community College of Allegheny College (CCAC). More use of our community college system to retrain displaced workers has merit. The relative cost of tuition is low as most community colleges are heavily subsidized by state and local governments. The course offerings are wide and scheduled class time very flexible. A recent 2010 Brookings Institution Policy Brief on "Retraining Displaced Workers" has some interesting ideas of how to enhance retraining at our community colleges through Pell Grants and other Federal aid and building more incentives for the college to retrain displaced workers. (Brookings, 2010) 


\section{References}

Anderson, Robert L. (1996), Steel Worker Lore Oral History, Project \#93-01, U.S. Steelworker Museum, Homestead, PA

Brookings Institution, the Hamilton Project (2010), Retraining Displaced Workers, Policy Brief, October

Chicago Tribune, "U.S. Steel Plant 'Not Profitable”, August 16

Corbett, J (1985), A study of unemployment in the Mon-Yough valley and its impact on social and psychological functioning, McKeesport, PA, Mon-Yough Community Mental Health and Mental Retardation Center, July

Crandall, Robert W. (1980), “Steel Imports Dumping or Competition?” Regulation, July/August

Franklin, Lena, personal communication, September 21, 2011

Ichniowski, Casey (1981), "Have Angels Done More? The Steel Industry Consent Decree," NBER Working Paper No. 674, May

Jacobson, Louis S. and Robert J. LaLonde (2005), Do Displaced Workers Benefit from Community College Courses? Findings from Administrative Data and Directions for Future Research, Conference on the Effects of Community Colleges on the Earnings of Displaced Workers, October

Jacobson, Louis S., Robert J. LaLonde and Daniel G. Sullivan (1993), "Earnings Losses of Displaced Workers, American Economic Review, v83, n4, September

Jesperse, Svend T., Jakob R. Munch, and Lars Skipper, (2008) "Costs and benefits of Danish active labour market programmes, "Labour Economics, October, vol 15, issue 5.

Kodrzycki, Yolanda K. (1997), "Training Programs for Displaced Workers: What Do They Accomplish?" New England Economic Review, May/June

Koehler, Norm, personal communication, September 14, 2011

Lechner, Michael and Conny Wunsch (2009), “Are Training Programs More Effective When Unemployment Is High?” Journal of Labor Economics, October, vol 27, no 4.

Leff, Janet (1986) "United States Steel Corp. and the Steel Valley Authority," under the supervision of Assistant Professor Douglas D. Anderson, University of Harvard Business School

Leigh, Duane E. (1994), Retraining Displaced Workers: The US Experience, ILO report no. ISBN-92-2-109256-9

Leigh, Duane E. (1990), Does Training Work Foe Dislocated Workers: A Survey of Existing Evidence, the Upjohn Institute for Employment Research 
Locker/Albrecht Associates (1985), Report to the United Steelworkers of America on the effectiveness of retraining programs for displaced Chicago steelworkers, AFI-CIO, CLC, December 16

McCollester, Charles, personal communication, September 15, 2011

Meager, Nigel (2009), "The role of training and skills development in active labour market policies," International Journal of Training and Development," vol 13, issue 1

New York Times (1986), Verbatim: Looking for a lifeline, August 10.

Oursler, Barney, personal communication, September 14, 2011

O'Malley, Jack, personal communication, September 14, 2011

O’Leary, Christopher J. (2010) Policies for Displaced Workers: An American Perspective, Upjohn Institute Working Paper 10-170, March

Quinn, Ronald, personal communication, September 15, 2011

Stout, Michael, personal communication, September 21, 2011

University of Pittsburgh, School of Social Work (1986), Survey of Workers in Duquesne, Pennsylvania: Recovery efforts by households and their members

University of Pittsburgh (1990), State of the Region Report, November

Winter-Ebmer (2006), "Coping with a structural crisis: evaluating an innovative redundancytraining project," International Journal of Manpower, vol 27, issue 8. 


\section{Appendix I}

\section{Survey}

Post training outcomes of displaced steel mill workers

\section{Information needed}

- Demographics - age, race, gender

- Type of training received

- Current work status - working FT or PT, not working but searching, or not working (retired, disabled, etc.)

○ If working, for whom and job tasks, tenure

- If not working and searching, how long looking

- If not working or searching, how long since last job

- Work history

○ First job after training - for whom, job tasks and tenure

- Second job after training (if applies) - for whom, job tasks and tenure and why left $1^{\text {st }}$ job

○ Third job after training (if applies) - for whom, job tasks and tenure and why left $2^{\text {nd }}$ job

- Etc until all jobs are covered

- Services used, if any, to help find or hold job 


\section{Questionnaire}

Q1. Background information
a. Date of birth
b. Gender
c. Race
d. $\quad$ Married
e. Veteran status

Q2. What type of training did you receive from the Allegheny County Pennsylvania Department of Federal Programs?
a. Job search (how to find a job)
b. Vocational (name field of study)
c. Other (describe it)

Q3. $\quad \underline{\text { Job lost }}$

a. for whom did you work

b. how many hours each week do you typically work

c. how much do earn per hour (if give earnings weekly, monthly or annually, convert to hourly using typical weekly hours figure)

d. how long did you work for them

e. what were your job tasks 
Q4. Pertains to your work history

$\underline{1^{\text {st }} \text { job after training }}$

a. for whom did you work

b. how many hours each week do you typically work

c. how much do earn per hour (if give earnings weekly, monthly or annually, convert to hourly using typical weekly hours figure)

d. how long did you work for them

e. what were your job tasks

f. why did you leave $1^{\text {st }}$ job

$\underline{\text { 2nd job after training }}$

a. for whom did you work

b. how many hours each week do you typically work

c. how much do earn per hour (if give earnings weekly, monthly or annually, convert to hourly using typical weekly hours figure)

d. how long did you work for them

e. what were your job tasks

f. why did you leave $2^{\text {nd }}$ job 


\section{$\underline{\text { 3rd job after training }}$}

a. for whom did you work

b. how many hours each week do you typically work

c. how much do earn per hour (if give earnings weekly, monthly or annually, convert to hourly using typical weekly hours figure)

d. how long did you work for them

e. what were your job tasks

f. why did you leave $3^{\text {rd }}$ job

$\underline{4^{\text {th }} \text { job after training (repeat } \mathrm{a}-\mathrm{f} \text { for each job held) }}$

Q5. What is your current work status?

a. Are you working if no, skip to b.

(i) If working, how many hours each week do you typically work

(ii) If working, how much do earn per hour (if give earnings weekly, monthly or annually, convert to hourly using typical weekly hours figure)

(iii) If working, for whom

(iv) If working, how long have to been working for (use answer in (iii)

(v) If working, what are your main job tasks (principal job if you had more than one job)

b. If not working, are you looking for work

c. If not working but looking for work, how many weeks have you been looking _-

d. If not working and not looking for a job, how long has it been since you last had a job 
Q6. Services used to help find and/or to help keep a job

a. did you use any services from your local employment office (one-stop)

b. if yes, what services did you use

c. did you use services from other local agencies e.g. health-related, welfare, child care, etc.

d. if yes, what agencies or organizations

e. if yes, what services did you use 